\section{Use of Sulphur Dioxide against the Bedbug}

SULPHUR dioxide, usually obtained by burning sulphur, when used as a fumigant for bug-infested houses, has not always been successful. Schlupp ${ }^{1}$, Gunn $^{2}$ and others have suggested that the eggs of the bedbug (Cimex lectularius L.) were more resistant than adults to sulphur dioxide. Fetscher ${ }^{3}$, however, recorded adults surviving at concentrations which killed the eggs.

I have carried out laboratory experiments to determine the relative resistance of different stages of the bedbug to sulphur dioxide. Using a fumigation apparatus similar to that described by Bovingdon ${ }^{4}$, I have exposed different stages of the bedbug for $2 \frac{1}{2}$ hours to known concentrations of this gas under controlled conditions of temperature and humidity. A summary of these results, expressed as the amount of sulphur dioxide required to give a complete kill of each stage at $23^{\circ} \mathrm{C}$. and 60 per cent relative humidity, is given below.

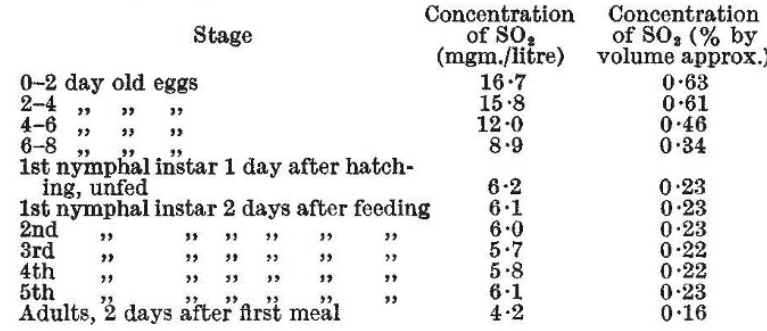

It appears, therefore, that the egg, especially just after being laid, is considerably more resistant to sulphur dioxide than either the adult or any nymphal instar, and that this resistance gradually decreases as the time of hatching approaches.

These results are part of an investigation carried out under the direction of Prof. J. W. Munro on behalf of the Committee on Bedbug Infestation of the Medical Research Council.

Biological Field Station, Imperial College of Science, Slough, Bucks.

1 Schlupp, W. F., J. Dept. Agric. S. Africa, 4, 132 (1922).

2 Gunn, W. C., "The Bedbug". Prevention of House Infestation. Dept. Hith. Scotland, 2 (1933).

${ }^{3}$ Fetscher, R., Reichsgesundheitblatt, Nos. 11 and 12 (1927).

'Bovingdon, H. H. S., Ann. Applied Biol., 21, 4 (1934).

\section{Stomatal Movement and Epidermal Water-Content}

IN a recent paper, F. J. Nutman ${ }^{1}$ has described the behaviour of the stomata of the coffee plant and directed attention to their remarkable sensitiveness to insolation. Within three minutes of exposure to direct sunlight the stomata begin to close, even though the water supply is abundant. Moreover, the closure is reversible: shading a single leaf on an insolated plant results in opening of the stomata of the shaded leaf. This is quite outside the normal range of stomatal behaviour hitherto described.

It seems possible, however, that results obtained in my laboratory by Dr. H. A. Razvi ${ }^{2}$ may provide a clue. Following up the observation that the stomata of certain succulents are sensitive to atmospheric humidity, Dr. Razvi discovered that their behaviour, in the leaves of Kleinia articulata and Sedum album, is not correlated with the watercontent of the leaf as a whole, for a turgid leaf in a dry atmosphere will open its stomata less widely than a leaf with a considerable water deficit in a saturated atmosphere.

These observations direct attention to the water content of the epidermis as the effective factor. In a dry atmosphere cuticular transpiration, if considerable, would reduce the water-content of the epidermis in relation to the mesophyll. Stomatal transpiration would affect primarily the subepidermal mesophyll and so the epidermis itself. In succulent leaves the vascular organization is not very efficient, and the gradients of water deficit would be correspondingly steep. In a saturated atmosphere, these gradients would be equalized, or possibly the epidermal watercontent raised above that of the rest of the leaf by direct absorption, without affecting the total leaf water-content recognizably.

In normal leaves, it is possible that lateral movement of water through the epidermis itself is the main channel of supply to the epidermal cells, direct from the veins. La Rue $^{3}$ observed in Mitchella repens that the epidermis remains alive and normal even when it becomes entirely separated from the underlying tissues except at the midrib and the margins of the leaf. The wavy outline characteristic of the stomatal epidermis in so many plants must reduce the resistance to lateral passage of water from cell to cell. Freer movement of water through the epidermis would tend towards uniformity of stomatal behaviour.

Since epidermal water-content is the factor directly affecting stomatal movement, and since it may be relatively independent of the water-content of the mesophyll, it is conceivable that insolation of coffee leaves may act by lowering the epidermal watercontent although the leaf as a whole remains turgid. The possibility could readily be tested, for the effect should not be observed, or should be reversed, in a saturated atmosphere. Coating the leaf with 'Vaseline' should have a similar effect.

\section{University College of North Wales,}

D. Thoday.

\section{Bangor.}

Dec. 28.

${ }^{1}$ Nutman, F. J., Ann. Bot., (N.S.) 1, 681 (1937).

${ }^{2}$ Razvi, H. A., Ph.D. thesis (Wales, 1937).

${ }^{3}$ La Rue, C. D., Mich. Acad. Sci., Arts and Letters, 13, 131 (1931).

\section{Structure of Permian Homsptera and Psocoptera}

THE recent note in $\mathrm{NATURH}^{1}$ on the ancestors of some groups of existing insects prompts me to mention certain facts apparently overlooked by Prof. G. Zalessky, and to direct attention to others bearing on the subject. Zalessky announces his discovery that the Permian Psocoptera had a "proboscisshaped" head, provided with a sucking apparatus similar to that of the Homoptera. In $1933^{2}$ I gave a detailed account, which is not mentioned by Zalessky, of the body structure of the Kansan Permian Psocoptera, and demonstrated then (Fig. 13, and plate 1, Fig. 4) that the head possessed a prominent rostrum. The significant feature of the rostrum of these Psocoptera is the presence of large and generalized maxillary and labial palpi, which are scarcely suggestive of the structure of the piercing beak of the Homoptera. Zalessky also states that he doubts the correctness of Dr. R. J. Tillyard's description of the chewing mouth-parts in Psocidium. This description I corrected in $1932^{3}$ and at the same time showed Psocidium Till. to be a synonym of Dichentomum Till., as it was later regarded by Dr. Tillyard4. 